\title{
The Impact of Digital Marketing System on Weaving Crafts Sales Growth in Buleleng Regency
}

\author{
Ida Bagus Koman Suarmaja ${ }^{1, *}$ I Wayan Cipta ${ }^{1}$ Ni Nyoman Yulianthini ${ }^{1}$ Fridayana \\ Yudiaatmaja $^{1}$
}

${ }^{1}$ Department of Management, Universitas Pendidikan Ganesha, Singaraja, Indonesia

*Corresponding author. Email: ibsuarmaja@gmail.com

\begin{abstract}
The purpose of this study was to (1) see the application of digital marketing to Micro, Small, and Medium Enterprises (MSMEs), especially weaving fabric in Kalianget Village, Buleleng Regency, and (2) to know the impact of digital marketing on the sales volume of woven handicraft products in Kalianget Village, Buleleng Regency. This research is a descriptive observational study on Endek weaving craftsmen, using the triangulation method, which combines structured interviews, in-depth interviews and observations of weaving craftsmen and the social media used. The data obtained were analyzed using descriptive statistics and qualitative analysis and presented in tabular form. The results of the study show that endek weaving craftsmen use social media as a means to run their business, which is not the least of which is a hereditary business from their ancestors. The most widely used social media are Facebook, Whatsaap, and Instagram. The most perceived benefit is that communication with customers and suppliers is more intensive as well as effective and efficient, because it can communicate directly 24 hours/real time. The transaction process is easier and cheaper because the communication media only costs credit to support communication. The best promotional media because it can display and share images through the media to the community and society. Information updates can be done at any time. The most importantly an average increase in sales volume of $50 \%-$ $100 \%$.
\end{abstract}

Keywords: Digital marketing, Sales volume, Weaving craftsmen.

\section{INTRODUCTION}

The weaving craft industry that produces endek fabric in Buleleng Regency has a great opportunity to develop, because of the policy of the Buleleng Regional Government to use endek fabric as a uniform for civil servants in the Buleleng Regency Government and other agencies. Endek cloth market opportunities are increasingly wide open, this is related to the Circular Letter of the Governor of Bali Number 4 of 2021 concerning the Use of Balinese Endek Woven Fabrics/ Balinese Traditional Woven Fabrics which in essence conveys and appeals to all agency leaders (state, private, BUMN, BUMD, Institutions/Society Organizations) in Bali urge all staff to wear clothes/tops made of Balinese Endek Woven Fabrics/Balinese Traditional Woven Fabrics [1]

In Bali, there are various types of woven fabrics that are occupied by craftsmen from various regions.
Kalianget Village is one of the villages where the community is engaged in woven fabric crafts. The woven fabrics made by the craftsmen in this village are endek mastuli woven fabrics, dobol silk, jumputan silk.

Kalianget Village is a village located in Seririt District, Buleleng Regency, Bali Province. In this village, apart from the people who are engaged in handicrafts, some of them also work in agriculture or plantations. Endek cloth is another name for Balinese ikat cloth, while the term mastuli refers to the type of silk thread used in the weaving process. Since the COVID-19 pandemic entered the territory of Indonesia, MSMEs in Buleleng Regency have not been able to carry out their usual activities to earn income in order to meet their daily needs [2]. Therefore, it is necessary to carry out recovery by innovating in order to remain active during this pandemic, one of which is utilizing technological developments as an effective promotional tool. 
ICT advancements are increasing at an exponential rate. Businesses of all sizes are taking advantage of this new technology to operate their operations. In a highly competitive market, the number of competitors is an important factor for entrepreneurs [2]. In order to reach the target market and improve sales and profits, appropriate marketing and media techniques are employed. Digital marketing is one of the most popular methods of promoting a wide range of products and services to the general public. They are slowly but surely abandoning the traditional/conventional marketing paradigm in favor of digital marketing, which is more current. As a result of digital marketing, businesses can communicate and conduct transactions throughout the world at any time. MSMEs can take advantage of the growing number of chat-based social media users, as well as the fact that the number of chatbased social media users is expanding every day [3][4].

In early 2021, there were 202.6 million Internet users in Indonesia. When compared to January 2020, this number grew by $15.5 \%$ or 27 million individuals. Currently, there are 274.9 million Indonesians in the entire country. Internet penetration in Indonesia would reach 73.7 percent by early 2021, according to this forecast [5].

Weaving craftsmen in Kalianget Village promoted their endek cloth to close friends and family. Over time, this activity has become a serious activity that mothers want to undertake to increase and support the household economy. The problem that arises is how to determine the right marketing strategy so that this home industry product can be quickly recognized and widely accepted, because so far the communication and transactions that occur are still using conventional and traditional systems, word of mouth and because they know each other. The phenomenon that exists is that the location of this endek weaving craftsman is not on the edge but a 500-1000m radius from a major highway.

Digital marketing may be an extremely effective strategy for weavers looking to promote their crafts. Similarly, to how autos and smartphones altered people's habits, digital marketing has the potential to do the same for businesses and their customers. permit clients to travel anywhere and at any time without regard for geographical or time limitations [6].

Market segmentation is growing more extensive as marketing reach extends with digital marketing's multiple advantages, including improved segmentation via the internet. Because it is available to everyone in the world, the internet has no geographical boundaries when it comes to marketing. In terms of cycle time, develop strategies more quickly. Marketing plans can also be created more swiftly in a more fluid flow of time. Higher standards of accountability have been placed on marketing initiatives. The company's strategy can continue to be developed with the help of fast and easy access to information. As a result, marketing may be done in a more open and honest way. Marketing and operational strategies are now more closely aligned. An integrated marketing strategy that includes both online and offline marketing efforts will be beneficial to both corporate and operational objectives [7].

Sales volume is affected by a variety of factors, including promotion, advertising, product quality, and price. In addition, social media and search engine optimization (SEO) [8] are part of digital marketing. Mobile phones or smartphones of the latest generation are already used by weavers. Previously, direct phone calls, SMS (short messaging service), and now people use social media to make offers like Facebook, Whatsapp, and Instagram to communicate. In this study, the author focuses on weaving craftsmen's use of social media as a means of boosting sales. Because of the complexity of SEO and the fact that weavers rarely use it, they are currently just relying on their smartphones and the features they provide.

In light of the foregoing, the authors would like to investigate if digital marketing, including social media, has an effect on the growth of weaving craft sales in Buleleng Regency, particularly in Kaliaget Village.

\section{METHOD}

In this study, the methodology is broken down into the research design and research subjects, data gathering methods, and data analysis methods, respectively. This study employs the triangulation technique, which combines structured interviews with in-depth interviews and observations of artisans who used social media, to conduct an observational descriptive study on the endek weaving industry in Kalianget Village, Buleleng Regency [9]. The subjects in this study were craftsmen who were selected by purposive sampling. Subjects were selected according to the criteria: 1) they are craftsmen, 2) have used social media in their business communication, 3) are willing to be research subjects. The total subjects recruited in the study were 30 people.

Craftsmen were interviewed in structured interviews and in-depth interviews as part of this study's primary data collection. The information gathered includes information on the endek weaving craft industry's usage of social media, such as goals, benefits, and challenges encountered. Data was examined using descriptive statistics and qualitative analysis and presented in tabular form.

\section{RESULTS \& DISCUSSION}

The results and discussion of this study are divided into the characteristics of the cottage industry business which is the subject of the study, the use of home industry social media and the influence of the use of social media for the cottage industry. 


\subsection{Characteristics of Endek Weaving Crafts}

The subjects in this study were craftsmen who made endek weaving crafts with the characteristics of the type of material, specifications of woven fabrics and the length of time in the weaving business, as shown in Table 1.

\subsection{Use of social media}

As a means of promoting their businesses, craftsmen use social media to spread the word about their work. Whatsapp is the most widely used social media by craftsmen. Whatsapp is used to chat customer to follow up the purchase. Facebook is used to displaying company profiles and their products. Instagram is used for product pictures. Most of the craftsmen budgeted Rp. 100,000-300,000,- per month to buy phone credit as a means of managing social media, providing information and business communication. In fact, they routinely update the information displayed on social media every day, as shown in Table 2.

Craftsmen can benefit greatly from the use of social media in a variety of ways, including being able to communicate directly with customers, promoting their work, tracking client preferences, and receiving feedback, all of which can help them make better business decisions. Online discussion forums, client surveys, data collection on dealer/agent needs, and product photographs are just some of the other uses of social media. In Table 3, the data is shown.

Using social media as a marketing tool for their home sector items has been a huge success for the weavers. Craftsmen's continued use of social media in product development, communication with consumers and customers, distributors, and the development of a bigger market network, resulting in increased sales volumes, is one of the driving factors [10][11]. Individuals can express themselves and meet and share with colleagues through the internet technology of social media, as defined by [12]. When it comes to finding, reading, talking, and sharing information with others in the modern world, social media represents a major shift. Due to social media's convenience and chances for people to connect online via personal connections, politics, and business, it has become increasingly popular. Additionally, social media serves as a platform for social interaction.

Furthermore, below is a table about the most beneficial use of social media for weaving craftsmen, as shown in Table 4.

Table 1. Characteristics of Endek Weaving Crafts

\begin{tabular}{|l|l|r|r|}
\hline \multicolumn{1}{|c|}{ No. } & \multicolumn{1}{|c|}{ Characteristics } & \multicolumn{1}{|c|}{ Total } & \\
\hline 1 & Material type & 20 & 66,66 \\
& a. Silk & 10 & 33.34 \\
\hline 2 & b. Cotton & 15 & 50 \\
& Tenun Endek Spesifications & 5 & 16,66 \\
& a. Endek Mastuli & 10 & 33,34 \\
& b. Endek Dobol & & \\
& C. Endek Jumputan & 3 & 10 \\
\hline 3 & Business Length & 10 & 33,34 \\
& a. $<$ years & 17 & 56,66 \\
\hline
\end{tabular}

Table 2. Social Media used

\begin{tabular}{|l|l|l|l|}
\hline No. & Characteristics & Total & Percentage (\%) \\
\hline 1 & Social Media used & 30 & 100 \\
& a. Whatsapp & 20 & 66,67 \\
& b. Facebook & 5 & 16,67 \\
\hline 2 & C. Instagram & & \\
& Phone Credit Spend & 15 & 50 \\
& a. Rp 50.000 - Rp 100.000 & 5 & 16,66 \\
& b. Rp 110.000 - Rp 200.000 & 10 & 33,34 \\
\hline \multirow{3}{*}{ c. Rp 210.000 - Rp 300.000 } & & \\
& Information update Frequency & 3 & 10 \\
& a. Every Hour & 15 & 50 \\
& b. Every Day & 10 & 33,34 \\
& c. Every Week & 2 & 6,66 \\
\hline & d. Every Month & & \\
\hline
\end{tabular}


Table 3. Benefits of Using social media

\begin{tabular}{|l|l|l|l|}
\hline \multicolumn{1}{|c|}{ No. } & \multicolumn{1}{|c|}{ Characteristics } & \multicolumn{1}{c|}{ Percentage (\%) } \\
\hline 1 & Direct contact with the customer & 30 & 100 \\
\hline 2 & Media to promote the products & 30 & 83,33 \\
\hline 3 & Delivering a response to consumers & 25 & 83,33 \\
\hline 5 & Follow up the customers & 25 & 66,67 \\
\hline 6 & Record customer needs & 20 & 100 \\
\hline 7 & Show photos of craft products & 30 & 66,67 \\
\hline 8 & Make a decision to transaction & 20 & 83,33 \\
\hline 9 & Record consumer demand & 25 & 100 \\
\hline 10 & Discussion forum & 30 & 66,67 \\
\hline 11 & Customer survey & 20 & 100 \\
\hline
\end{tabular}

Table 4. The Most Benefit of Use Social Media

\begin{tabular}{|c|c|}
\hline $\begin{array}{l}\text { The most appropriate use of social } \\
\text { media }\end{array}$ & Statements of endek weaving craftsmens \\
\hline Increase sales volume & $\begin{array}{l}\text { "Before using WA and FB, my orders were few, only from close people, friends, } \\
\text { and collectors who usually come directly to the house. But now there has been } \\
\text { an increase in sales, even profits above } 5 \text { million per month" } \\
\text { "In the past, if the customer wanted to transfer, I was a little hesitant, because } \\
\text { the proof of the transfer couldn't be displayed, now there is a WA that can be } \\
\text { photographed and I became convinced" } \\
\text { "I can show products with new motifs on Instagram and FB, so that many } \\
\text { orders come from outside the region and even outside Bali" } \\
\text { "After using social media, I flooded with orders, sometimes I refused because I } \\
\text { was worried because I couldn't finish on time, because it took a long process to } \\
\text { do it" } \\
\text { "Many new customers because they are promoted through social media where } \\
\text { almost everyone already has a smartphone" }\end{array}$ \\
\hline $\begin{array}{l}\text { Effective and efficient } \\
\text { communication media }\end{array}$ & $\begin{array}{l}\text { "Using social media really makes it easier to communicate with customers" } \\
\text { "I use WA more often, and I can be contacted at any time to ask questions } \\
\text { about products or place orders" } \\
\text { "With the data-saving package, it makes my communication with customers and } \\
\text { suppliers of raw materials easier and cheaper" } \\
\text { "I can receive orders according to the customer's wishes through the pictures } \\
\text { that are sent and because there is a phone credit package it becomes cost- } \\
\text { effective" }\end{array}$ \\
\hline $\begin{array}{l}\text { Improving business skills through } \\
\text { social media }\end{array}$ & $\begin{array}{l}\text { "After using a smartphone my business activities have become more } \\
\text { developed" } \\
\text { "I can make transactions easily by using mobile banking" } \\
\text { "The payment system that I do can be by transfer, it's easier and faster" } \\
\text { "I am increasingly able to play social media to develop my business and be } \\
\text { widely known, as well as add resellers from various regions" }\end{array}$ \\
\hline
\end{tabular}


This study found that craftsmen who use social media get more orders from clients. Communication is also effective and efficient since it saves time and money. They will be able to engage personally, as well as build their business through agents or distributors. Based on cross-sectional interviews with endek weavers, sales volume increases are compared before and after adopting social media.

\section{CONCLUSION}

The conclusion that can be drawn from this research is that endek weaving craftsmen use social media as a means to carry out their business, which is not a small business passed down from their ancestors. Facebook, Whatsapp, and Instagram are the three most popular social media platforms. Customers and suppliers are able to contact directly 24 hours a day/365 days a year, making it more effective and efficient. Because the communication media simply costs credit to facilitate communication, the transaction process is easier and more cost-effective. The best way to get your message out to the public is through the media, which allows you to display and distribute photographs to the community and society. It is possible to make changes to the data at any moment. Most importantly, there was a $100 \%$ rise in sales volume on average.

Endek weaving craftsmen are advised to optimize the development of existing information technology to the maximum. This means starting to make new innovations in promoting their products to make them more attractive by utilizing existing social media, so that an increase in sales volume can continue to increase and develop.

\section{REFERENCES}

[1] BPASPEM Provinsi Bali, "Surat Edaran Nomor 04 Tahun 2021 Tentang Penggunaan Kain Tenun Endek Bali/Kain Tenun Tradisional Bali,” 2021. https://bpadpem.baliprov.go.id/wp/2021/05/10/su rat-edaran-nomor-04-tahun-2021-tentangpenggunaan-kain-tenun-endek-bali-kain-tenuntradisional-bali/. (accessed Sep. 05, 2021).

[2] Balitbang Buleleng, "9 Terhadap Umkm Di Buleleng," 2021. https://balitbang.bulelengkab.go.id/informasi/det ail/artikel/76-dampak-pandemi-covid-19terhadap-umkm-di-buleleng, 2021. (accessed Sep. 25, 2021).

[3] A. Wardhana, "Strategi Digital Marketing dan Implikasinya Pada Keunggulan Bersaing UMK di Indonesia," in In Seminar Nasional Keuangan dan Bisnis IV, 2021, pp. 327-337.
[4] A. Wardhana, Strategi Digital Marketing dan Implikasinya Pada Keunggulan Bersaing UMK di Indonesia. In Seminar Nasional Keuangan dan Bisnis IV (pp. 327-337). Universitas Pendidikan Indonesia, 2015.

[5] G.P. Riyanto "Jumlah Pengguna Internet Indonesia 2021 Tembus 202 Juta ", Klik untuk baca: https://tekno.kompas.com/read/2021/02/23/ 16100057/jumlah-pengguna-internet-indonesia2021-tembus-202-juta, 2021.

[6] P.K. Kannan, and 1. Hongshuang, Digital Marketing: A Framework, Review and Research Agenda. International Journal of Research in Marketing, 2016.

[7] F. Khan, and K. Siddiqui, The Importance of Digital Marketing: An Exploratory Study to Find The Perception and Effectiveness of Digital Marketing amongst The Marketing Proffesionals in Pakistan. Journal of Information Sytems and Operations Management, 1-8, 2013.

[8] S. Zhang, and N. Cabage, Search engine optimization: Comparison of link building and social sharing. Journal of Computer Information Systems, 57(2), 148-159. 2016.

[9] Sugiyono, Metode Penelitian Kuantitatif, Kualitatif, dan R\&D. Bandung: Alfabeta, 2018.

[10] Jonathan Sarwono and K. Prihartono Perdagangan, Online: Cara Bisnis di Internet, Elex media Komputindo, Jakarta, 2010.

[11] P. Mandal, Understanding Digital Marketing Strategy, International Journal of Scientific Research and Management, 1, 1-4, 2017, doi:10.18535/ijsrm/v5i6.11

[12] L. Safko, and K.B. David, The Social Media Bible: Tactics, Tools, and Strategies for Business Success, John Wiley \& Sons: New Jersey, 2009. 